\title{
Antioxidant and Hepatoprotective Effect of Aqueous Extract of Germinated and Fermented Mung Bean on Ethanol-Mediated Liver Damage
}

\author{
Norlaily Mohd Ali, ${ }^{1}$ Hamidah Mohd Yusof, ${ }^{1}$ Kamariah Long, ${ }^{2}$ \\ Swee Keong Yeap, ${ }^{3}$ Wan Yong Ho, ${ }^{1}$ Boon Kee Beh, ${ }^{4}$ Soo Peng Koh, \\ Mohd Puad Abdullah, ${ }^{1}$ and Noorjahan Banu Alitheen ${ }^{1}$ \\ ${ }^{1}$ Department of Cell and Molecular Biology, Faculty of Biotechnology and Biomolecular Sciences, \\ University Putra Malaysia, 43400 Serdang, Selangor, Malaysia \\ ${ }^{2}$ Department of Bioprocess Biotechnology, Malaysian Agriculture Research Development Institute, \\ 43400 Serdang, Selangor, Malaysia \\ ${ }^{3}$ Institute of Bioscience, University Putra Malaysia, 43400 Serdang, Selangor, Malaysia \\ ${ }^{4}$ Department of Bioprocess Technology, Faculty of Biotechnology and Biomolecular Sciences, \\ University Putra Malaysia, 43400 Serdang, Selangor, Malaysia
}

Correspondence should be addressed to Noorjahan Banu Alitheen; noorjahan@biotech.upm.edu.my

Received 30 August 2012; Revised 25 October 2012; Accepted 26 October 2012

Academic Editor: Andre Van Wijnen

Copyright (C) 2013 Norlaily Mohd Ali et al. This is an open access article distributed under the Creative Commons Attribution License, which permits unrestricted use, distribution, and reproduction in any medium, provided the original work is properly cited.

\begin{abstract}
Mung bean is a hepatoprotective agent in dietary supplements. Fermentation and germination processes are well recognized to enhance the nutritional values especially the concentration of active compounds such as amino acids and GABA of various foods. In this study, antioxidant and hepatoprotective effects of freeze-dried mung bean and amino-acid- and GABA-enriched germinated and fermented mung bean aqueous extracts were compared. Liver superoxide dismutase (SOD), malondialdehyde (MDA), ferric reducing antioxidant power (FRAP), nitric oxide (NO) levels, and serum biochemical profile such as aspartate transaminase (AST), alanine transaminase (ALT), triglycerides (TG), and cholesterol and histopathological changes were examined for the antioxidant and hepatoprotective effects of these treatments. Germinated and fermented mung bean have recorded an increase of 27.9 and 7.3 times of GABA and 8.7 and 13.2 times of amino acid improvement, respectively, as compared to normal mung bean. Besides, improvement of antioxidant levels, serum markers, and NO level associated with better histopathological evaluation indicated that these extracts could promote effective recovery from hepatocyte damage. These results suggested that freeze-dried, germinated, and fermented mung bean aqueous extracts enriched with amino acids and GABA possessed better hepatoprotective effect as compared to normal mung bean.
\end{abstract}

\section{Introduction}

Liver is a pivotal inflammatory organ that, involved in metabolism, storage, and excretion of metabolites. There are considerable numbers of hepatotoxins that have been reported to cause a liver damage such as ethanol, paracetamol, and carbon tetrachloride [1-5]. The mice model of liver injuries induced by various hepatotoxins showed similar trend but with slight variations such as increased membrane permeability, lipid peroxidation, and cell death which was comparable to development of chronic hepatic disease in humans. Upon stimulation from various hepatotoxins, Kupffer cells which release proinflammatory mediators such as NO and Interferon-gamma (IFN- $\gamma$ ) will eventually result in accumulation of reactive nitrogen species (ROS). ROS has been shown to cause lipid peroxidation and membrane degradation which will generate liver damage and inflammation $[1,3,5,6]$. Natural sources of antioxidantssuch as green tea has been reported to increase the level of SOD and FRAP in cytoplasm of rat's liver which reverted the injury 
effect close to normal [7]. Polyphenols, flavonoids, and anthocyanins have been suggested to exert strong antioxidant activity, which contribute to the protective effect of against liver injury in rats $[4,7]$.

Mung bean (Vignaradiata), which is mainly cultivated in East Asia and South Asia regions contains rich source of protein, essential amino acids, minerals, vitamins, and fibers. It has been renowned of having multinutritional values as well as medicinal properties. Earlier studies have demonstrated that mung bean can act as an antioxidant $[2,8]$, liver protection [9] and antidiabetic agent due to its low glycemic index $[10,11]$. Recently, it was reported that the ethanolic extract of mung bean exhibits antiinflammatory response by decreasing the proinflammatory cytokines in mouse macrophages $[5,12]$. Germination and fermentation have been well associated with the elevated amount of antioxidants and GABA content [13-16]. GABA ( $\gamma$-amino butyric acid) is a nonprotein amino acids that acts as a neuron inhibitors in mammals, which can be extracted from plant. Numerous studies have proclaimed that the roles of GABA as an antihypertension, anticancer, and antiinflammatory agents and its other healthful benefits [17-19]. These aspects have stimulated the interest to generate GABA-enriched natural products. Fermented soybean product, GABA-Tempeh, is a traditional food that contains abundance of oligopeptides and free amino acids (mainly GABA) which contribute to lower level of cholesterol in plasma [18]. This effect can be correlated with liver function as lipid metabolism in body. Therefore, by undergoing germination and fermentation processes, freeze-dried mung bean aqueous extracts could contribute to liver protective effect and other healthful benefits. Wu et al. [9] were the first to report the hepatoprotective effects of mung bean. Their study compared the histological and biochemistry changes of acetaminophen-induced liver injury and the ameliorate properties of different Taiwan's legumes such as adzuki bean, black bean, rice bean, and mung bean. Mung bean aqueous extract was identified to exhibit the best hepatoprotective effects among the legumes against liver injury agent, acetaminophen.

To date, no in vivo test has been conducted to assess the effect of freeze-driedgerminated and fermented mung bean aqueous extracts on animal model. The purposes of this study wereto compare the in vivo antioxidant enzymes content and hepatoprotective effects of freeze-dried normal mung bean, nutrient-enriched germinated, and fermented mung bean aqueous extracts on ethanol-induced liver damage mice model. This study also aimed to establish the correlation between the effects of fermentation and germination on amino acids and GABA level of mung bean and the hepatoprotective properties of the extracts.

\section{Materials and Methods}

2.1. Materials. Hypoxanthine, xanthine oxidase, superoxide dismutase, Folin-Ciocalteu reagent, aluminium chloride, sodium nitrate, ascorbic acid, and gallic acid were purchased from Sigma-Aldrich (USA). All solvents used were either of analytical reagent or HPLC grade. Griess reagent was from
Invitrogen (USA). The Rhizopus sp. strain of 5351 inoculums was obtained from MARDI's (Malaysian Agricultural Research and Development Institute) culture collection center. Milk thistle extracts containing $80 \%$ of silybin was obtained from Lipa Pharmaceutical Pty. Ltd. (Australia).

2.2. Animals. Male Balb/c mice of $8-10$ weeks old weighing 20-25g were maintained under standard condition of temperature $\left(22 \pm 5^{\circ} \mathrm{C}\right)$ and humidity in animal house with $12 \mathrm{~h}$ of light/dark cycle. Animals were provided with food and water ad libitum. Experiments were strictly conducted and approved by Animal Care and Use Committee, Universiti Putra Malaysia, (Ref: UPM/FPV/PS/3.2.1.551/AUP-R2).

2.3. Plant Material. Mung bean (Vignaradiata) seeds were purchased from the local store in Selangor. The mung bean seeds were allowed to undergo solid-state fermentation base on our previous method [20] and germination process prior to extraction. For fermented mung bean [20], about $1000 \mathrm{~g}$ of dehulled mung bean seeds were soaked in cold water at room temperature for $18 \mathrm{~h}$. Soaked mung beans were washed thoroughly and steamed for 40 minutes. After that, steamed seeds were cooled to room temperature and subsequently mixed with Rhizopus sp. strain of 5351 inoculums. From our previous preliminary studies (data not shown), mung bean seeds were screened with different Rhizopus sp. strains (5346, $5347,5351,5375,5376,5377,5408$, and 5410). The results revealed that Rhizopus sp. strain 5351 yielded the highest total amino acids and GABA content in fermented mung bean after $48 \mathrm{~h}$ of incubation at $30^{\circ} \mathrm{C}$. Following this, the hepatoprotective effects of fermented mung bean inoculated with 5351 strain were evaluated. The inoculated beans were then packed into perforated plastics and incubated for $48 \mathrm{~h}$ at $30^{\circ} \mathrm{C}$. Finally, all fermented mung bean seeds were dried and ground into powder prior to water extraction. On the other hand, germinated mung bean seeds was prepared by germinating the mung beans seeds inside the container Anaerocult $A$ supplied with $\mathrm{CO}_{2}$ gas for up to $72 \mathrm{~h}$. Germinated seeds were then allowed to dry until constant moisture content was obtained and ground into powder prior to water extraction. For control, mung bean seeds were directly ground into powder without prior fermentation or germination.

Finely ground powder was then extracted using deionised water $\left(1: 20\right.$ ratio) at $25^{\circ} \mathrm{C}$ for 30 minutes and placed in an incubator shaker at $300 \mathrm{rpm}$ for 30 minutes under room temperature. Mixture was then centrifuged for 5 minutes at $10,000 \mathrm{rpm}$ andthe supernatant was collected. Supernatants were furthersubjected to freeze-dry at operating temperature of $-50^{\circ} \mathrm{C}$ (yield $25 \%, \mathrm{w} / \mathrm{w}$ ). The freeze-dried powder was stored at $4^{\circ} \mathrm{C}$. The assays were performed according to [2022] with slight modifications.

2.3.1. GABA and Amino Acids Determination. The freezedried powder was dissolved in distilled water and filtered through $0.2 \mu \mathrm{m}$ syringe filter prior to UPLC analysis. The derivatization process was done by mixing $70 \mu \mathrm{L}$ of AccQTag Ultra borate buffer with $10 \mu \mathrm{L}$ of filtered extracts solution, 
followed by adding $20 \mu \mathrm{L}$ of AccQ Fluor reagent in $1.5 \mathrm{~mL}$ eppendorf tube. All analyses were performed on a Waters Acquity UPLC system, comprised of a binary solvent manager, a sample manager fitted with $2 \mu \mathrm{L}$ sample loop and UV-PDA detector set at $260 \mathrm{~nm}$. The data were analyzed using Waters Empower 2 software. Acquity UPLC AccQ-Tag Ultra Column $(2.1 \mathrm{~mm}$ i.d. $\times 100 \mathrm{~mm} \times 1.7 \mu \mathrm{m}$ particle size $)$ was used for the determination of GABA and amino acids profile. The mobile phase used was AccQ-Tag Ultra Eluent A for mobile phase A and AccQ-Tag Ultra Eluent B for mobile phase $\mathrm{B}$. The gradient condition was: $0-0.54$ minutes, 0-0.1\% B; 0.54-5.74 minutes, $0.1-9.1 \%$ B; 5.74-7.74 minutes, 9.1-21.2\% B; 7.74-8.8 minutes, $21.2-59.6 \%$ B; $8.8-11$ minutes, $59.6-0.1 \% \mathrm{~B}$, and finally, reconditioning the column with $0.1 \%$ B with isocratic flow for 2.1 minutes after washing column with $59.6 \% \mathrm{~B}$ for 0.30 minutes. The flow rate was set at $0.7 \mathrm{~mL} / \mathrm{minutes}$ and the injection volumes for all samples and standards were $1.0 \mu \mathrm{L}$. The column temperature was set at $55^{\circ} \mathrm{C}$ according to $[20,23]$.

\subsection{In Vivo Hepatoprotective Effect-Ethanol Induced Hepa-} totoxicity in Mice. Total of $72 \mathrm{Balb} / \mathrm{c}$ mice were randomly distributed into eight groups $(n=8)$. Hepatoprotective effects of freeze-dried mung bean and fermented and germinated mung bean aqueous extracts were assessed in ethanolinduced liver damage animal model. Mice were pretreated orally with ethanol and plant aqueous extracts individually for up to 21 days. The experiment was designed as follows. Group 1. Normal group, mice (p.o.) with $100 \mu \mathrm{L}$ of normal saline for 14 days.

Group 2. Ethanol untreated group, mice (p.o.) with $100 \mu \mathrm{L}$ of $50 \%(\mathrm{v} / \mathrm{v})$ of ethanol for 7 days followed by 14 days of $100 \mu \mathrm{L}$ of 1 X PBS.

Group 3. Positive control group, mice (p.o.) with $100 \mu \mathrm{L}$ of $50 \%$ (v/v) of ethanol for 7 days followed by 14 days of $100 \mu \mathrm{L}$ of silybin $(50 \mathrm{mg} / \mathrm{kg})$.

Group 4. Low dose treated group, mice (p.o.) with $100 \mu \mathrm{L}$ of $50 \%(\mathrm{v} / \mathrm{v})$ of ethanol for 7 days followed by 14 days of $100 \mu \mathrm{L}$ of mung bean extract $(200 \mathrm{mg} / \mathrm{kg})$.

Group 5. High dose treated group, mice (p.o.) with $100 \mu \mathrm{L}$ of $50 \%(\mathrm{v} / \mathrm{v})$ of ethanol for 7 days followed by 14 days of $100 \mu \mathrm{L}$ of mung bean extract (1000 mg/kg).

Group 6. Low dose treated group, mice (p.o.) with $100 \mu \mathrm{L}$ of $50 \%(\mathrm{v} / \mathrm{v})$ of ethanol for 7 days followed by 14 days of $100 \mu \mathrm{L}$ of germinated mung bean extract $(200 \mathrm{mg} / \mathrm{kg})$.

Group 7. High dose treated group, mice (p.o.) with $100 \mu \mathrm{L}$ of $50 \%(\mathrm{v} / \mathrm{v})$ of ethanol for 7 days followed by 14 days of $100 \mu \mathrm{L}$ of germinated mung bean extract $(1000 \mathrm{mg} / \mathrm{kg})$.

Group 8. Low dose treated group, mice (p.o.) with $100 \mu \mathrm{L}$ of $50 \%(\mathrm{v} / \mathrm{v})$ of ethanol for 7 days followed by 14 days of $100 \mu \mathrm{L}$ of fermented mung bean extract $(200 \mathrm{mg} / \mathrm{kg})$.
Group 9. High dose treated group, mice (p.o.) with $100 \mu \mathrm{L}$ of $50 \%(\mathrm{v} / \mathrm{v})$ of ethanol for 7 days followed by 14 days of $100 \mu \mathrm{L}$ of fermented mung bean extract $(1000 \mathrm{mg} / \mathrm{kg})$.

At the end of the experimental period, mice were sacrificed by cervical dislocation. Blood serum was obtained via cardiac puncture and subjected to serum biochemistry analysis and liver was immediately collected. Weight of liver was recorded and expressed as a relative organ weight [24].

2.5. Serum Biochemistry. Activities of blood serum marker enzyme including alanine transaminase (ALT), aspartate aminotransferase (AST), triglyceride (TG), and total cholesterol were measured using biochemical analyzer (Hitachi 902 Automatic Analyzer) and adapted reagents from Roche (Germany).

2.6. Liver Histopathological Evaluation. Liver was removed, fixed in $10 \%$ formalin solution, embedded in paraffin, sectioned into 4 microns thickness, and stained with haematoxylin and eosin (H\&E) for assessment of histopathological alterations. Histopathological changes of stained livers were observed under bright-field microscope. Assessment of liver was graded based on vascular and necrotic changes according to [25]. Vascular changes include vessel congestion, leakage of erythrocytes into surroundings, and hematoma formation. Necrotic changes show the appearance of necrosis, fibrosis, and cell regeneration. No change (no distinguishable change, $0 \%)$; mild change (30\%); moderate change (31-60\%); severe change (61-90\%); very severe change (91-100\%).

2.7. In Vitro Antioxidants of Liver Homogenate Evaluation. Mice liver were meshed in ice-cold PBS and homogenized before centrifuged at $2000 \mathrm{rpm}$ for 5 minutes at $4^{\circ} \mathrm{C}$. Supernatant was collected and subjected to different assays including superoxide dismutase (SOD) [26], malondialdehyde (MDA) [27], ferric reducing antioxidant power (FRAP) [28] and nitric oxide (NO) assay [29].

2.7.1. Determination of Superoxide Dismutase (SOD). Briefly, SOD was determined following the method of evaluating the inhibition of the reduction of nitro blue tetrazolium (NBT) of liver homogenates. Briefly, sample was added with $0.1 \mathrm{~mol} / \mathrm{L}$ EDTA, $0.15 \mathrm{mg} / \mathrm{mL}$ sodium cyanide, $1.5 \mathrm{mmol} / \mathrm{L}$ NBT, $0.12 \mathrm{mmol} / \mathrm{L}$ riboflavin, and $0.067 \mathrm{~mol} / \mathrm{L}$ phosphate buffer to a final volume of $300 \mu \mathrm{L}$. The reduction was measured at $560 \mathrm{~nm}$ and percentage of SOD inhibition as compared to the blank was determined. One unit of SOD was calculated by the amount of protein needed to achieve the $50 \%$ inhibition and hence expressed as unit SOD/mg protein.

2.7.2. Determination of Malondialdehyde (MDA). Liver peroxidation was detected by measuring thiobarbituric acidreactive substance (TBARS). In brief, aliquot of $100 \mu \mathrm{L}$ liver homogenate was diluted with $400 \mu \mathrm{L}$ of PBS $(8.1 \mathrm{~g} \mathrm{NaCl}$, $2.302 \mathrm{~g} \mathrm{Na}_{2} \mathrm{HPO}_{4}$, and $0.194 \mathrm{~g} \mathrm{NaH}_{2} \mathrm{PO}_{4} / \mathrm{L}$ ) and mixed with $12.5 \mu \mathrm{L}$ butyhydroxytoulene (BHT, $8.8 \mathrm{mg} / \mathrm{mL}$ ) and $250 \mu \mathrm{L}$ 
trichloroacetic acid (TCA, 30\%). The mixture was vortexed and kept on ice for $2 \mathrm{~h}$. Next, mixture was centrifuged at $2000 \mathrm{~g}$ for $15 \mathrm{~min}$. Supernatant obtained was boiled for $15 \mathrm{~min}$ along with $37.5 \mu \mathrm{L} 0.1 \mathrm{M}$ EDTA and $125 \mu \mathrm{L}$ thiobarbituric acid (TBA, 1\%). After mixture has been cooled down to room temperature, the absorbance of pink-colored product was taken at 532 and $600 \mathrm{~nm}$ wavelength using ELISA Reader (Bio-tek Instrument, USA). The difference between absorbance was measured and compared to that of the standard malonaldehyde tetramethyl acetal solutions of different concentrations. MDA activity was expressed as nmol MDA/g protein.

\subsubsection{Determination of Ferric Reducing Antioxidant Power} (FRAP). The FRAP was determined from reduction of $\mathrm{Fe}^{3+}$ to $\mathrm{Fe}^{2+}$ according to standard method with some modification. Reagent was prepared by mixing $300 \mathrm{mM}$ acetate buffer $\left(3.1 \mathrm{~g} \mathrm{C}_{2} \mathrm{H}_{3} \mathrm{NaO}_{2} \cdot 3 \mathrm{H}_{2} \mathrm{O}\right.$ and $\left.16 \mathrm{~mL} \mathrm{C}_{2} \mathrm{H}_{4} \mathrm{O}_{2}\right), 10 \mathrm{mM}$ TPTZ (2, 4, 6-tripyridyl-s-triazine) solution, and $20 \mathrm{mM}$ $\mathrm{FeCl}_{3} \cdot 6 \mathrm{H}_{2} \mathrm{O}$ solution in $40 \mathrm{mM} \mathrm{HCl}$. The fresh working solution was prepared by mixing $25 \mathrm{~mL}$ acetate buffer, $2.5 \mathrm{~mL}$ TPTZ solution, and $2.5 \mathrm{~mL} \mathrm{FeCl} \cdot 6 \mathrm{H}_{2} \mathrm{O}$ solution and then warmed at $37^{\circ} \mathrm{C}$ before using. Aliquot of $150 \mu \mathrm{L}$ of bioactive extract $(5 \mathrm{mg} / \mathrm{mL})$ from mung bean, germinated, and fermented beans was allowed to react with $2850 \mu \mathrm{L}$ of FRAP solution and shaken vigorously before being incubated in the dark for $30 \mathrm{~min}$. The reading of the colored product (ferrous tripyridyltriazine complex) was taken at $593 \mathrm{~nm}$. The FRAP activity was calculated from the standard $\mathrm{FeSO}_{4}$ calibration curve and FRAP value was expressed as $\mu \mathrm{M} \mathrm{Fe}^{2+} / \mathrm{mg}$ protein.

2.7.4. Determination of Nitric Oxide. Briefly, NO production in liver was determined using a calorimetric Griess reaction (Invitrogen, USA). Liver homogenates $(100 \mu \mathrm{L})$ was loaded onto microtitre plate, followed by $100 \mu \mathrm{L}$ Griess reagent ( $1 \%$ sulphanilamide and $0.1 \% \mathrm{~N}$-1-naphthylethylenediamine dihydrochloride in $2.5 \%$ polyphosphoric acid). Later, the absorbance was taken at $540 \mathrm{~nm}$ wavelength using ELISA Reader (Bio-tek Instrument, USA).

2.8. Statistical Analysis. All quantitative measurements were conveyed as mean \pm SD Analyses were performed using oneway analysis of variance (ANOVA) and the group means were compared by Duncan test. $P<0.05$ was considered as statistically significant.

\section{Results}

3.1. GABA and Amino Acids Content. We have previously reported that fermented mung bean contained 7.6 times and 13.2 times higher GABA and amino acids contents as compared to normal dried mung bean powder [20]. Similarly, germinated mung bean also showed an increase in GABA and amino acids concentration by 27.9 times and 8.7 times to $0.502 \pm 0.035 \mathrm{~g} / 100 \mathrm{~g}$ and $2.092 \pm 0.117 \mathrm{~g} / 100 \mathrm{~g}$ of dried powder, respectively.

\subsection{In Vivo Hepatoprotective Effect}

3.2.1. Effect of Aqueous Extracts on Liver Function Biomarkers. ALT and AST are two biochemical markers normally used for early stage assessment of liver injury. Table 1 shows that ethanol had significantly raised serum ALT and AST level in mice liver as compared to normal group indicating the incident of liver injury. The serum ALT level was successfully brought down in all posttreatment groups with high doses of mung bean, germinated and fermented mung bean extracts $(1000 \mathrm{mg} / \mathrm{kg})$. In contrast, the serum ALT level in all low doses of mung bean extracts $(200 \mathrm{mg} / \mathrm{kg}$ ) treated groupswere continued to rise, indicating that the functions of liver have been compromised. In all extract-treated groups of both concentrations, the serum markers of AST were reduced to lower than the ethanol-attenuated group. Treatment with fermented mung bean at high dose $(1000 \mathrm{mg} / \mathrm{kg})$ displayed the highest suppression percentage of serumALT $(63.73 \%)$ and AST (69.84\%) followed by germinated mung bean high dose (1000 mg/kg), 45.25\% (ALT) and 47.75\% (AST), when compared to ethanol control group.

The above results showed that fermented mung beans at high dose $(1000 \mathrm{mg} / \mathrm{kg})$ were able to retain the serum ALT and AST closest to the normal level and has better performance than the standard drug, silybin.

3.2.2. Effect of Aqueous Extracts on Serum TG and Cholesterol. Another hallmark to confirm the acute alcohol-induced liver injury was indicated by elevated serum TG and cholesterol level. As shown in Table 1, treatment with extracts subsided the boosted level of TG and cholesterol with significant reduction in high dose fermented mung bean $(1000 \mathrm{mg} / \mathrm{kg})$ with $38.4 \%$ and $23.42 \%$, respectively.

3.3. Effect of Aqueous Extracts on the Level of SOD, MDA, FRAP, and NO in Liver Homogenate. The effects of oral administration of mung bean, germinated, and fermented mung bean aqueous extracts on liver antioxidant were shown in Table 2. After being intoxicated with ethanol, a decline in the level of superoxide dismutase (SOD) and ferric reducing antioxidant power (FRAP) was observed in liver injury groups (ethanol-induced) when compared to normal group. Yet, SOD level increased back to normal in all extractstreated mice with low $(200 \mathrm{mg} / \mathrm{kg} /$ day $)$ and high doses (1000 mg/kg/day) of mung bean, germinated, and fermented mung beans. On the other hand, MDA and NO levels were markedly increased in ethanol-attenuated liver, hallmarks of lipid peroxidation, and inflammatory response. Significant decrease in MDA and NO production were noticed in all aqueous extract-treated groups. Fermented mung bean was able to reduce MDA level by 3.6 times from $7.17 \pm 0.17$ to $2.00 \pm 0.23(\mathrm{nmol} / \mathrm{g}$ of protein) and NO level by 1.6 times from $14.72 \pm 0.75$ to $9.03 \pm 0.06(\mu \mathrm{mol} / \mathrm{mg}$ of protein). Meanwhile, it also elevated the SOD enzyme level and FRAP activity by 2.3 and 2.2 times, respectively, which essentially contribute to hepatoprotective effects against free radicals. Thehighest dose of fermented mung bean $(1000 \mathrm{mg} / \mathrm{kg} /$ day $)$ was found to be the most comparable to normal and standard drug silybingroups. 
TABLE 1: Effect of mung bean extracts on serum ALT, AST, TG, and cholesterol in alcohol-induced acute liver toxicity in mice.

\begin{tabular}{|c|c|c|c|c|}
\hline Treatment & $\operatorname{ALT}(\mathrm{U} / \mathrm{L})$ & $\operatorname{AST}(\mathrm{U} / \mathrm{L})$ & $\mathrm{TG}(\mathrm{mmol} / \mathrm{L})$ & Cholesterol (mmol/L) \\
\hline Normal untreated & $14.09 \pm 1.53$ & $98.16 \pm 1.99$ & $1.48 \pm 0.23$ & $3.14 \pm 0.39$ \\
\hline 50\% EtOH (placebo) & $48.11 \pm 1.78$ & $367.30 \pm 1.10$ & $2.37 \pm 0.14$ & $3.80 \pm 0.20$ \\
\hline $50 \%$ EtOH + silybin (50 mg/kg) & $26.72 \pm 1.20^{*}$ & $171.70 \pm 3.79^{*}$ & $2.77 \pm 0.16$ & $4.20 \pm 0.36$ \\
\hline $50 \%$ EtOH + mung bean $(200 \mathrm{mg} / \mathrm{kg})$ & $63.44 \pm 2.73^{*}$ & $294.50 \pm 6.28^{*}$ & $2.06 \pm 0.22^{*}$ & $3.28 \pm 0.31^{*}$ \\
\hline $50 \% \mathrm{EtOH}+$ mung bean $(1000 \mathrm{mg} / \mathrm{kg})$ & $28.09 \pm 1.32^{*}$ & $234.19 \pm 6.87^{*}$ & $2.05 \pm 0.44^{*}$ & $3.29 \pm 0.41^{*}$ \\
\hline $\begin{array}{l}50 \% \text { EtOH }+ \text { germinated } \\
\text { mung bean }(200 \mathrm{mg} / \mathrm{kg})\end{array}$ & $57.57 \pm 3.60^{*}$ & $308.61 \pm 1.33^{*}$ & $2.21 \pm 0.06^{*}$ & $3.40 \pm 0.01^{*}$ \\
\hline $\begin{array}{l}50 \% \text { EtOH }+ \text { germinated } \\
\text { mung bean }(1000 \mathrm{mg} / \mathrm{kg})\end{array}$ & $26.34 \pm 3.50^{*}$ & $191.93 \pm 1.51^{*}$ & $1.84 \pm 0.35^{*}$ & $3.13 \pm 0.06^{*}$ \\
\hline $\begin{array}{l}50 \% \text { EtOH }+ \text { fermented } \\
\text { mung bean }(200 \mathrm{mg} / \mathrm{kg})\end{array}$ & $56.26 \pm 4.71^{*}$ & $232.48 \pm 1.52^{*}$ & $2.26 \pm 0.12^{*}$ & $3.18 \pm 0.21^{*}$ \\
\hline $\begin{array}{l}50 \% \text { EtOH }+ \text { fermented } \\
\text { mung bean }(1000 \mathrm{mg} / \mathrm{kg})\end{array}$ & $17.45 \pm 1.88^{*}$ & $110.77 \pm 6.96^{*}$ & $1.46 \pm 0.76^{*}$ & $2.91 \pm 0.19^{*}$ \\
\hline
\end{tabular}

Values are mean \pm SEM of 8 animals each in a group and significantly different from the $50 \%$ EtOH (Placebo) $\left({ }^{*} P<0.05\right)$ by ANOVA and followed by Duncan's multiple range test.

TABLE 2: Effect of mung bean extracts on SOD, MDA, FRAP, and NO levels in liver homogenate of alcohol-induced acute liver toxicity in mice.

\begin{tabular}{|c|c|c|c|c|}
\hline Treatment & $\begin{array}{c}\text { SOD } \\
\text { (U/mg of protein) }\end{array}$ & $\begin{array}{l}\text { MDA (nmol/g of } \\
\text { protein) }\end{array}$ & $\begin{array}{c}\text { FRAP } \\
\text { (U/mg of protein) }\end{array}$ & $\begin{array}{c}\mathrm{NO} \\
(\mu \mathrm{mol} / \mathrm{mg} \text { of protein })\end{array}$ \\
\hline Normal untreated & $16.58 \pm 0.58^{*}$ & $3.02 \pm 0.16^{*}$ & $9.40 \pm 1.04^{*}$ & $9.97 \pm 0.25^{*}$ \\
\hline $50 \%$ EtOH (placebo) & $9.17 \pm 0.79$ & $7.17 \pm 0.17$ & $5.33 \pm 0.04$ & $14.72 \pm 0.75$ \\
\hline $50 \%$ EtOH + silybin $(50 \mathrm{mg} / \mathrm{kg})$ & $17.06 \pm 0.01^{*}$ & $4.92 \pm 0.20^{*}$ & $14.97 \pm 0.08^{*}$ & $9.39 \pm 2.70^{*}$ \\
\hline $50 \% \mathrm{EtOH}+$ mung bean $(200 \mathrm{mg} / \mathrm{kg})$ & $16.48 \pm 2.72^{*}$ & $3.74 \pm 0.25^{*}$ & $8.82 \pm 0.25^{*}$ & $11.04 \pm 0.39^{*}$ \\
\hline $50 \% \mathrm{EtOH}+$ mung bean $(1000 \mathrm{mg} / \mathrm{kg})$ & $17.07 \pm 3.77^{*}$ & $3.78 \pm 0.33^{*}$ & $5.63 \pm 0.01$ & $10.29 \pm 0.11^{*}$ \\
\hline $\begin{array}{l}50 \% \mathrm{EtOH}+\text { germinated mung bean } \\
(200 \mathrm{mg} / \mathrm{kg})\end{array}$ & $16.64 \pm 0.73^{*}$ & $2.54 \pm 0.20^{*}$ & $9.83 \pm 0.02^{*}$ & $9.54 \pm 0.04^{*}$ \\
\hline $\begin{array}{l}50 \% \mathrm{EtOH}+\text { germinated mung bean } \\
(1000 \mathrm{mg} / \mathrm{kg})\end{array}$ & $17.11 \pm 1.26^{*}$ & $2.31 \pm 0.26^{*}$ & $5.74 \pm 0.02$ & $8.84 \pm 0.42^{*}$ \\
\hline $\begin{array}{l}50 \% \mathrm{EtOH}+\text { fermented mung bean } \\
(200 \mathrm{mg} / \mathrm{kg})\end{array}$ & $18.00 \pm 0.34^{*}$ & $3.22 \pm 0.32^{*}$ & $5.52 \pm 0.02$ & $10.78 \pm 0.03^{*}$ \\
\hline $\begin{array}{l}50 \% \mathrm{EtOH}+\text { fermented mung bean } \\
(1000 \mathrm{mg} / \mathrm{kg})\end{array}$ & $21.35 \pm 0.44^{*}$ & $2.00 \pm 0.23^{*}$ & $11.92 \pm 0.03^{*}$ & $9.03 \pm 0.06^{*}$ \\
\hline
\end{tabular}

Values are mean \pm SEM of 8 animals each in a group and significantly different from the $50 \% \mathrm{EtOH}$ (placebo) $\left({ }^{*} \mathrm{P}<0.05\right)$ by ANOVA and followed by Duncan's multiple range test.

3.4. Histopathological Evaluation. Histopathology assessment of liver was performed for all groups. Figure 1(a) shows that there was no pathological abnormality observed in the liver of normal mice and thus showing the absence of vascular or necrosis changes. Figure 1(b) shows that ethanol induced severe necrosis changes and substantial changes in liver section such as ballooning, microvesicular steatosis, increase in sinusoidal space (SS) dilation and central vein, and lymphocytes cells infiltration in sinusoids in ethanoluntreated group as compared to normal group. The striking feature observed in ethanol-induced liver was in various stages of cytoplasmic condensation, microvesicular steatosis, and hepatocytes necrosis indicating early phases of liver injury. On the other hand, livers of mice in all aqueous extractstreated groups showed noticeable recovery from ethanolinduced liver damage when compared to ethanol untreated group with less microvesicular steatosis and hepatocytes necrosis features. Moderate necrosis changes were noticed in all low doses of mung bean extracts-treated groups (Figures 1(d), 1(f), and 1(h)). The high dose of mung bean, germinated, and fermented mung bean aqueous extractstreated groups illustrated mild necrosis and inflammatory changes, with less severity than changes observed after ethanol administration (Figures 1(e), 1(g), and 1(i)). Reduced degree of sinusoidal and central vein dilations, ballooning, and hepatocytes necrosis were noticed particularly in germinated and fermented mung beanat high dose $(1000 \mathrm{mg} / \mathrm{kg})$ (Figure 1(g)).

\section{Discussion}

Ethanol has been reported as an eminent contributor to liver and kidney injury in humans and animals who have been exposed to excess ethanol for a certain period of 


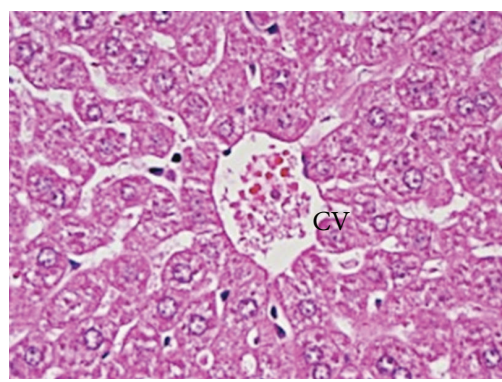

(a)

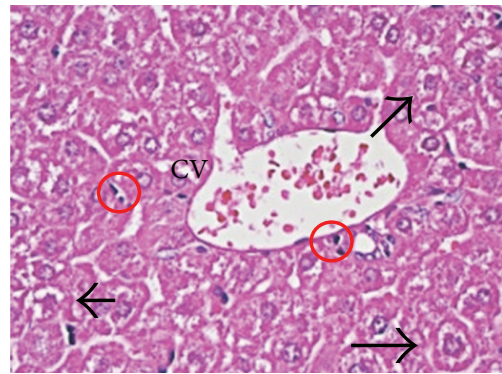

(d)

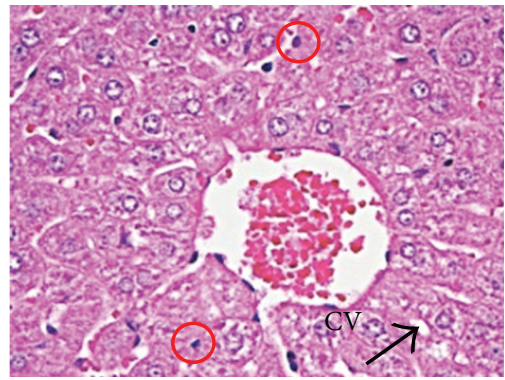

(g)

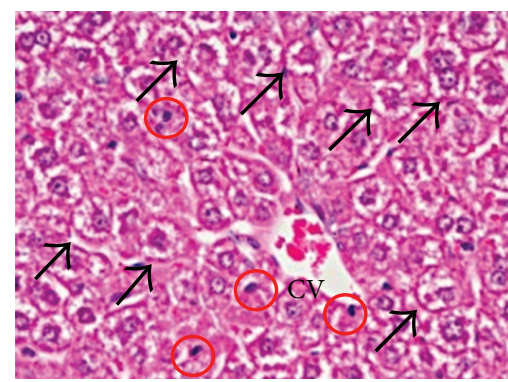

(b)

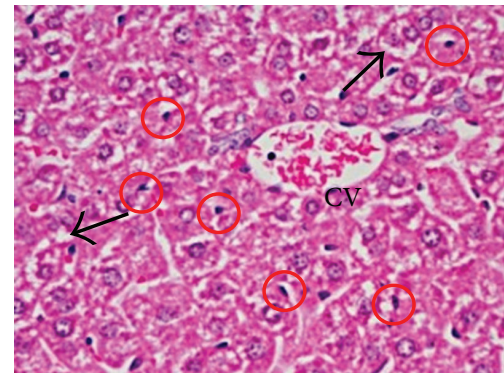

(e)

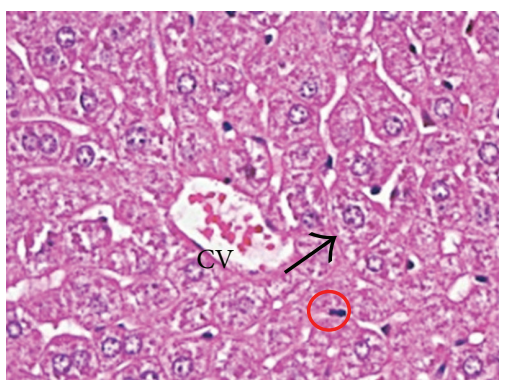

(h)

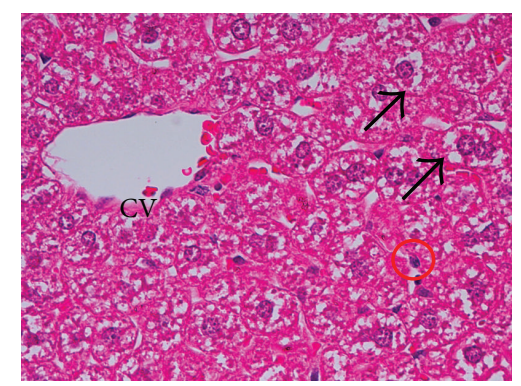

(c)

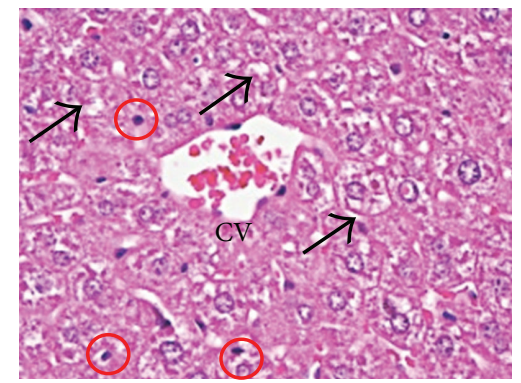

(f)

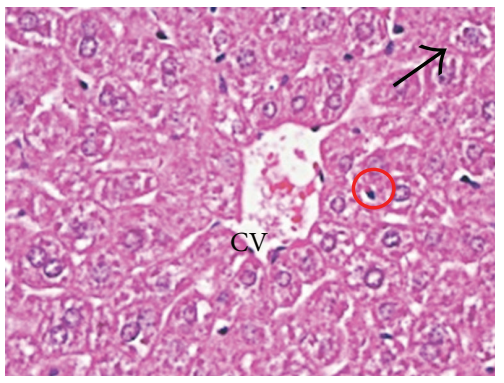

(i)

FIGURE 1: The photomicrographs $(40 \times 10)$ of liver section taken from mice. Normal group $(a)$ received saline as a normal control group, shows a normal structure of central vein surrounded by hepatic cells, (b) received saline after being induced with $50 \%$ ethanol as a ethanol control group, shows a steatosis and hepatocyte necrosis; (c) received Silybin $(50 \mathrm{mg} / \mathrm{kg}$ body wt.) after being induced with $50 \%$ ethanol; (d) received mung bean ( $200 \mathrm{mg} / \mathrm{kg}$ body wt.) after being induced with $50 \%$ ethanol; (e) received mung bean ( $1000 \mathrm{mg} / \mathrm{kg}$ body wt.) after being induced with $50 \%$ ethanol; (f) received germinated mung bean $(200 \mathrm{mg} / \mathrm{kg}$ body wt.) after being induced with $50 \%$ ethanol; (g) received germinated mung bean $(1000 \mathrm{mg} / \mathrm{kg}$ body wt.) after being induced with $50 \%$ ethanol; (h) received fermented mung bean (200 mg/kg body wt.) after being induced with $50 \%$ ethanol; (i) received fermented mung bean (1000 mg/kg body wt.) after being induced with $50 \%$ ethanol. Significant hepatoprotective effects are seen in extracts-treated particularly germinated and fermented mung bean. Arrow indicates a condition of microvesicular steatosis in liver injury, which mainly occurs in ethanol-induced group. Circle indicates hepatocytes necrosis. Centrilobular vein $(\mathrm{CV})$.

time $[1,30]$. Ethanol metabolism can trigger protein, lipid, and DNA degradation due to free radicalsformation. The result of the present study supports the work of previous published reports using natural extracts to treat ethanolinduced mice, as a model for acute liver disease $[31,32]$. Features of ethanol-attenuated hepatocytes include inflammation, apoptosis, and necrosis including cirrhosis. In addition, prolonged exposure to ethanol has been shown to increase the level of TNF- $\alpha$, a proinflammatory cytokines, which in turn can trigger other inflammatory chemokine, explicitly, NO. Decrease in antioxidant defense and elevation of serum markers such as AST, ALT, TG, and cholesterol were also observed [4, 33]. Furthermore, numerous studies have reported the association of antioxidant in the protection against oxidative liver injury $[5,34,35]$.

To assess the hepatoprotective properties of extracts, in vivo study were performed to measure the serum markers and chemokine presence in it. According to Koch et al. [33], ethanol catabolism will result in surplus of NADH and acetyl-CoA thus causing lipogenesis of cholesterol and TG and also the leakage of cellular enzymes into plasma associated with serum ALT and AST. These will eventually contribute to liver injury. Thus, by restoring the level of serum ALT, AST, cholesterol, and TG back to normal, high dose 
of fermented mung beans has certified its hepatoprotective effects at least in part. Moreover, in the present study, hepatoprotective effects of mung bean was compared against germinated and fermented mung beans extracts. Higher degree of reduction in serum ALT, AST, cholesterol, and TG content were observed in germinated and fermented mung bean groups as compared to mung bean groups. Nonetheless, mung bean extracts also contributed to slight decline of those serum biomarkers. Our result was in agreement with previous works done on fermented food products where the induced serum markers were significantly restored back to normal through in vivo [36] and in vitro [19] studies.

The antioxidant properties of extracts were examined in mice liver tissue via MDA, SOD, FRAP, and NO assay. Increased amount of MDA in ethanol-induced liver signifies the enhance degree of lipid peroxidation, which can lead to liver damage. On contrary, SOD and FRAP levels in ethanol-induced group were decreased. A decrease in both activities in liver tissue of ethanol-induced group was largely due tothe impairment of antioxidant enzymes that safeguard cells against reactive oxygen species [31]. On the other hand, increase in SOD and FRAP levels and decrease in MDA formation in fermented and germinated extracts-treated groups were as expected. High total phenolic content and strong antioxidant activity were claimed in fermented [37, $38]$ and germinated mung bean [14,39]. This may be the reason for the increase of SOD and FRAP activities in germinated and fermented mung bean at high dose as compared to mung bean, which consequently reduced the MDA level. In addition, it has been reported that mung bean extract contains volatile antioxidant which was able to inhibit malonaldehyde formation in blood plasma [40].

$\mathrm{NO}$ is an inflammatory mediator and highly reactive oxidant produced by iNOS, which is released by kupffer cells upon exposure to hepatotoxins [5, 41]. In all extractstreated groups, NO level was reverted to normal level. High dose fermented mung bean extracts were the most effective extracts to revert the elevation of NO level after induction with ethanol followed by germinated mung bean extracts. Thus, by suppressing NO production in liver, germinated and fermented mung beans depicted their potential properties as hepatoprotective agent.

A plausible justification for hepatoprotective and antioxidant effects of germinated and fermented mung beans at high dose may be due to the presence of flavonoids and phenolic acids bioactive compounds, which were highly detected particularly in fermented and germinated products [14, 42]. Besides, many studies have reported on the increased content of GABA and amino acids in commercial legumes after undergoing germination [43-46] and fermentation [21, 47] processes. Elevation of amino acids and GABA in our germinated and fermented mung bean extracts may be well added to liver protection properties since GABA amino acids have been known to carry liver protection through the mechanism of maintenance of intracellular polyamines levels of ethanol and $\mathrm{CCl}_{4}$-exposed hepatic injury effects $[48,49]$.

In the present study, histological evaluation was undertaken to support the biochemistry profiles. The pathological changes observed in the ethanol-treated liver through $\mathrm{H} \& \mathrm{E}$ staining were related to the results obtained. Administration of ethanol in mice animal model revealed that elevated level of liver function biomarkers ALT, AST, TG, and cholesterol levels were detected along with the decrease of antioxidant activity and severe necrosis histopathological changes. However, possible hepatoprotective effect of germinated and fermented mung bean extracts was observed when attenuated liver was treated with extracts. Previous study has reported the hepatoprotective properties of their extract to reduce microvesicular steatosis and hepatocytes necrosis in chronic liver injury, which is in agreement with our study [9]. Liver injury hallmark such as inflammation, lymphocytes infiltration, necrosis and ballooning effects were restored back close to normal after administration of high dose of germinated and fermented mung bean extracts-treatment, supported by the decrease in ALT, AST, TG, cholesterol, NO, MDA and increase in FRAP and SOD activities. The correlation between liver biomarkers and histopathological changes suggested that they can be used for early detection of acute liver damage. Reduction of biochemical and histological damage was exerted by fermented and germinated mung bean, conforming their hepatoprotective properties.

No studies have been conducted on histopathological changes of fermented and germinated mung bean extracts on ethanol-attenuated liver. The biochemical and histopathological changes of attenuated liver after being treated with fermented and germinated mung bean were as expected since they contain more bioactive compounds compared to mung bean. Results prove that germinated and fermented mung bean exert better effects on liver injury than normal mung bean. This implies that the increase in amino acids, GABA, phenolic content, and other bioactives compounds during germination and fermentation processes contribute to the hepatoprotective effects of mung bean to ameliorate liver injury. Overall, fermented mung bean possessed the best antioxidant and hepatoprotective effect. This result gives us an idea that amino acid may play a more important role than GABA since we have observed better improvement of amino acid level in fermented than germinated mung bean but vice versa for GABA content.

\section{Conclusion}

To the best of our knowledge, no comparison studies have been made specifically between mung bean and germinated or fermented mung bean aqueous extracts in terms of their liver hepatoprotective and antioxidant enzyme properties. Freeze-dried fermented and germinated mung bean aqueous extracts at $1000 \mathrm{mg} / \mathrm{kg}$ body weight showed potential hepatoprotective effects on ethanol-induced liverinjury based on serum biochemical profile and histology evaluation of mice liver. This could be largely due to the amino acids content and antioxidant properties possessed by these extracts with regard to FRAP scavenging activity and oxidant-related factor, SOD. In conclusion, fermentation and germination increased the nutritional and medicinal values of mung bean. Moreover, the results are comparable with silybin, a standard drug typically prescribed to treat liver disease. Therefore, 
the results strongly imply the potential use of fermented and germinated mung bean aqueous extracts from natural product in future application for oxidative stress and liver disease therapy.

\section{Abbreviations}

ALT: Alanine transaminase

AST: Aspartate aminotransferase

GABA: $\gamma$-amino butyric acid

TG: $\quad$ Triglycerides

NO: $\quad$ Nitric oxide.

\section{Acknowledgment}

This project was funded by e-Science Fund under Ministry of Agriculture (MOA), Malaysia.

\section{References}

[1] M. M. Brzóska, J. Moniuszko-Jakoniuk, B. Piłat-Marcinkiewicz, and B. Sawicki, "Liver and kidney function and histology in rats exposed to cadmium and ethanol," Alcohol and Alcoholism, vol. 38, no. 1, pp. 2-10, 2003.

[2] N. E. Rocha-Guzmán, A. Herzog, R. F. González-Laredo, F. J. Ibarra-Pérez, G. Zambrano-Galván, and J. A. GallegosInfante, "Antioxidant and antimutagenic activity of phenolic compounds in three different colour groups of common bean cultivars (Phaseolus vulgaris)," Food Chemistry, vol. 103, no. 2, pp. 521-527, 2007.

[3] U. S. Satyapal, V. J. Kadam, and R. Ghosh, "Hepatoprotective activity of livobond a polyherbal formulation against CCl4 induced hepatotoxicity in rats," International Journal of Pharmacology, vol. 4, no. 6, pp. 472-476, 2008.

[4] V. R. L. López, G. S. Razzeto, M. S. Giménez, and N. L. Escudero, "Antioxidant properties of amaranthus hypochondriacus seeds and their effect on the liver of alcohol-treated rats," Plant Foods for Human Nutrition, vol. 66, no. 2, pp. 157-162, 2011.

[5] G. J. Huang, J. S. Deng, S. S. Huang, Y. Y. Shao, C. C. Chen, and Y. H. Kuo, "Protective effect of antrosterol from Antrodia camphorata submerged whole broth against carbon tetrachloride-induced acute liver injury in mice," Food Chemistry, vol. 132, no. 2, pp. 709-716, 2012.

[6] T. Liu, J. Zhao, L. Ma, Y. Ding, and D. Su, "Hepatoprotective effects of total triterpenoids and total flavonoids from Vitis vinifera L against immunological liver injury in mice," Evidence-Based Complementary and Alternative Medicine, vol. 2012, Article ID 969386, 8 pages, 2012.

[7] H. A. El-Beshbishy, O. M. Tork, M. F. El-Bab, and M. A. Autifi, "Antioxidant and antiapoptotic effects of green tea polyphenols against azathioprine-induced liver injury in rats," Pathophysiology, vol. 18, no. 2, pp. 125-135, 2011.

[8] F. Lai, Q. Wen, L. Li, H. Wu, and X. Li, "Antioxidant activities of water-soluble polysaccharide extracted from mung bean (Vigna radiata L.) hull with ultrasonic assisted treatment," Carbohydrate Polymers, vol. 81, no. 2, pp. 323-329, 2010.

[9] S. J. Wu, J. S. Wang, C. C. Lin, and C. H. Chang, "Evaluation of hepatoprotective activity of Legumes," Phytomedicine, vol. 8, no. 3, pp. 213-219, 2001.
[10] Z. Madar and A. H. Stark, "New legume sources as therapeutic agents," British Journal of Nutrition, vol. 88, no. 3, pp. S287-S292, 2002.

[11] Y. Yao, F. Chen, M. Wang, J. Wang, and G. Ren, "Antidiabetic activity of Mung bean extracts in diabetic KK-Ay mice," Journal of Agricultural and Food Chemistry, vol. 56, no. 19, pp. 8869-8873, 2008.

[12] S. J. Lee, J. H. Lee, H. H. Lee et al., "Effect of mung bean ethanol extract on pro-inflammtory cytokines in LPS stimulated macrophages," Food Science and Biotechnology, vol. 20, no. 2, pp. 519-524, 2011.

[13] M. J. R. Nout and J. L. Kiers, “Tempe fermentation, innovation and functionality: update into the third millenium," Journal of Applied Microbiology, vol. 98, no. 4, pp. 789-805, 2005.

[14] R. Fernandez-Orozco, J. Frias, H. Zielinski, M. K. Piskula, H. Kozlowska, and C. Vidal-Valverde, "Kinetic study of the antioxidant compounds and antioxidant capacity during germination of Vigna radiata cv. emmerald, Glycine max cv. jutro and Glycine max cv. merit," Food Chemistry, vol. 111, no. 3, pp. 622-630, 2008.

[15] Y. Z. Ding, S. Y. Zhang, P. Liu et al., "Microbiological and biochemical changes during processing of the traditional chinese food douzhi," Food Control, vol. 20, no. 12, pp. 1086-1091, 2009.

[16] A. Matsuyama, K. Yoshimura, C. Shimizu, Y. Murano, H. Takeuchi, and M. Ishimoto, "Characterization of glutamate decarboxylase mediating $\gamma$-amino butyric acid increase in the early germination stage of soybean (Glycine max [L.] Merr)," Journal of Bioscience and Bioengineering, vol. 107, no. 5, pp. 538-543, 2009.

[17] C. H. Oh and S. H. Oh, "Effects of germinated brown rice extracts with enhanced levels of GABA on cancer cell proliferation and apoptosis," Journal of Medicinal Food, vol. 7, no. 1, pp. 19-23, 2004.

[18] N. Watanabe, Y. Endo, K. Fujimoto, and H. Aoki, "Tempeh-like fermented soybean (GABA-tempeh) has an effective influence on lipid metabolism in rats," Journal of Oleo Science, vol. 55, no. 8, pp. 391-396, 2006.

[19] Y. M. Kang, Z. J. Qian, B. J. Lee, and Y. M. Kim, "Protective effect of GABA-enriched fermented sea tangle against ethanolinduced cytotoxicity in HepG2 cells," Biotechnology and Bioprocess Engineering, vol. 16, no. 5, pp. 966-970, 2011.

[20] S. K. Yeap, N. M. Ali, H. M. Yusof et al., "Antihyperglycemic effects of fermented and nonfermented mung bean extracts on alloxan induced-diabetic mice," Journal of Biomedicine and Biotechnology, vol. 2012, Article ID 285430, 7 pages, 2012.

[21] J. S. Tsai, Y. S. Lin, B. S. Pan, and T. J. Chen, "Antihypertensive peptides and $\gamma$-aminobutyric acid from prozyme 6 facilitated lactic acid bacteria fermentation of soymilk," Process Biochemistry, vol. 41, no. 6, pp. 1282-1288, 2006.

[22] Y. Guo, H. Chen, Y. Song, and Z. Gu, "Effects of soaking and aeration treatment on $\gamma$-aminobutyric acid accumulation in germinated soybean (Glycine max L.)," European Food Research and Technology, vol. 232, no. 5, pp. 787-795, 2011.

[23] W. Liming, Z. Jinhui, X. Xiaofeng, L. Yi, and Z. Jing, "Fast determination of 26 amino acids and their content changes in royal jelly during storage using ultra-performance liquid chromatography," Journal of Food Composition and Analysis, vol. 22, no. 3, pp. 242-249, 2009.

[24] S. Saravanan, B. N. Prakash, P. Pandikumar, R. M. Karunai, P. M. Gabriel, and S. Ignacimuthu, "Immunomodulatory potential of Enicostema axillare (Lam.) A. Raynal, a traditional 
medicinal plant," Journal of Ethnopharmacology, vol. 140, no. 2, pp. 239-246, 2012.

[25] A. Y. L. Lim, I. Segarra, S. Chakravarthi, S. Akram, and J. P. Judson, "Histopathology and biochemistry analysis of the interaction between sunitinib and paracetamol in mice," $B M C$ Pharmacology, vol. 10, no. 14, 2010.

[26] L. E. Ilouno, E. N. Shu, and G. E. Igbokwe, "An improved technique for the assay of red blood cell superoxide dismutase (SOD) activity," Clinica Chimica Acta, vol. 247, no. 1-2, pp. 1-6, 1996.

[27] M. Suhail and M. Faizul-Suhail, "Oxidant-antioxidant status in pair-matched maternal and cord blood of normotensive and preeclamptic patients," Journal of Chinese Clinical Medicine, vol. 4, no. 5, pp. 241-248, 2009.

[28] K. Thaipong, U. Boonprakob, K. Crosby, L. Cisneros-Zevallos, and D. Hawkins Byrne, "Comparison of ABTS, DPPH, FRAP, and ORAC assays for estimating antioxidant activity from guava fruit extracts," Journal of Food Composition and Analysis, vol. 19, no. 6-7, pp. 669-675, 2006.

[29] R. R. He, B. Tsoi, F. Lan, N. Yao, X. S. Yao, and H. Kurihara, "Antioxidant properties of lutein contribute to the protection against lipopolysaccharide-induced uveitis in mice," Chinese Medicine, vol. 6, no. 1, p. 38, 2011.

[30] P. Pramyothin, C. Ngamtin, S. Poungshompoo, and C. Chaichantipyuth, "Hepatoprotective activity of Phyllanthus amarus Schum. et. Thonn. extract in ethanol treated rats: in vitro and in vivo studies," Journal of Ethnopharmacology, vol. 114, no. 2, pp. 169-173, 2007.

[31] J. Du, D. He, L. N. Sun et al., "Semen Hoveniae extract protects against acute alcohol-induced liver injury in mice," Pharmaceutical Biology, vol. 48, no. 8, pp. 953-958, 2010.

[32] A. I. Ghoneim and O. A. Eldahshan, "Anti-apoptotic effects of tamarind leaves against ethanol-induced rat liver injury," The Journal of Pharmacy and Pharmacology, vol. 64, no. 3, pp. 430-438, 2012.

[33] O. R. Koch, S. Fusco, S. C. Ranieri et al., "Role of the life span determinant P66shcA in ethanol-induced liver damage," Laboratory Investigation, vol. 88, no. 7, pp. 750-760, 2008.

[34] A. Kshirsagar, A. Purnima, D. Ingawale, N. Vyawahare, K. Ingale, and A. Hadambar, "Antioxidant and hepatoprotective activity of Ethanolic extract of calotropis gigantea against Paracetamol induced liver damage in mice," Journal of Cell and Tissue Research, vol. 9, no. 2, pp. 1859-1864, 2009.

[35] W. Zhao, J. J. Li, S. Q. Yue, L. Y. Zhang, and K. F. Dou, "Antioxidant activity and hepatoprotective effect of a polysaccharide from Bei Chaihu (Bupleurum chinense DC)," Carbohydrate Polymers, vol. 89, no. 2, pp. 448-452, 2012.

[36] Z. A. Zakaria, M. S. Rofiee, M. N. Somchit et al., "Hepatoprotective activity of dried- and fermented-processed virgin coconut oil," Evidence-based Complementary and Alternative Medicine, vol. 2011, Article ID 142739, 2011.

[37] S. L. Wang, Y. C. Liang, and T. W. Liang, "Purification and characterization of a novel alkali-stable $\alpha$-amylase from Chryseobacterium taeanense TKU001, and application in antioxidant and prebiotic," Process Biochemistry, vol. 46, no. 3, pp. 745-750, 2011.

[38] D. K. Kim, S. C. Jeong, S. Gorinstein, and S. U. Chon, "Total polyphenols, antioxidant and antiproliferative activities of different extracts in mungbean seeds and sprouts," Plant Foods for Human Nutrition, vol. 67, no. 1, pp. 71-75, 2012.
[39] S. J. Lee and K. G. Lee, "Inhibitory effects of volatile antioxidants found in various beans on malonaldehyde formation in horse blood plasma," Food and Chemical Toxicology, vol. 43, no. 4, pp. 515-520, 2005.

[40] N. Amat, H. Upur, and B. Blažeković, "In vivo hepatoprotective activity of the aqueous extract of Artemisia absinthium L. against chemically and immunologically induced liver injuries in mice," Journal of Ethnopharmacology, vol. 131, no. 2, pp. 478-484, 2010.

[41] R. Randhir and K. Shetty, "Mung beans processed by solid-state bioconversion improves phenolic content and functionality relevant for diabetes and ulcer management," Innovative Food Science and Emerging Technologies, vol. 8, no. 2, pp. 197-204, 2007.

[42] P. Sikiric, S. Seiwerth, Z. Grabarevic et al., "Hepatoprotective effect of BPC 157, a 15-aminoacid peptide, on liver lesions induced by either restraint stress or bile duct and hepatic artery ligation or CCL4 administration. A comparative study with dopamine agonists and somatostatin," Life Sciences, vol. 53, no. 18, pp. PL291-PL296, 1993.

[43] N. Komatsuzaki, K. Tsukahara, H. Toyoshima, T. Suzuki, N. Shimizu, and T. Kimura, "Effect of soaking and gaseous treatment on GABA content in germinated brown rice," Journal of Food Engineering, vol. 78, no. 2, pp. 556-560, 2007.

[44] K. B. Park and S. H. Oh, "Production of yogurt with enhanced levels of gamma-aminobutyric acid and valuable nutrients using lactic acid bacteria and germinated soybean extract," Bioresource Technology, vol. 98, no. 8, pp. 1675-1679, 2007.

[45] H. J. Chung, S. H. Jang, H. Y. Cho, and S. T. Lim, "Effects of steeping and anaerobic treatment on GABA ( $\gamma$-aminobutyric acid) content in germinated waxy hull-less barley," Food Science and Technology, vol. 42, no. 10, pp. 1712-1716, 2009.

[46] A. A. Khalil, "Nutritional improvement of an Egyptian breed of mung bean by probiotic lactobacilli," African Journal of Biotechnology, vol. 5, no. 2, pp. 206-212, 2006.

[47] J. Y. Cha, J. J. Jeong, H. J. Yang, B. J. Lee, and Y. S. Cho, “Effect of fermented sea tangle on the alcohol dehydrogenase and acetaldehyde dehydrogenase in Saccharomyces cerevisiae," Journal of Microbiology and Biotechnology, vol. 21, no. 8, pp. 791-795, 2011.

[48] T. Norikura, A. Kojima-Yuasa, D. Opare Kennedy, and I. Matsui-Yuasa, "Protective effect of gamma-aminobutyric acid (GABA) against cytotoxicity of ethanol in isolated rat hepatocytes involves modulations in cellular polyamine levels," Amino Acids, vol. 32, no. 3, pp. 419-423, 2007.

[49] Y. H. Kuo, P. Rozan, F. Lambein, J. Frias, and C. Vidal-Valverde, "Effects of different germination conditions on the contents of free protein and non-protein amino acids of commercial legumes," Food Chemistry, vol. 86, no. 4, pp. 537-545, 2004. 

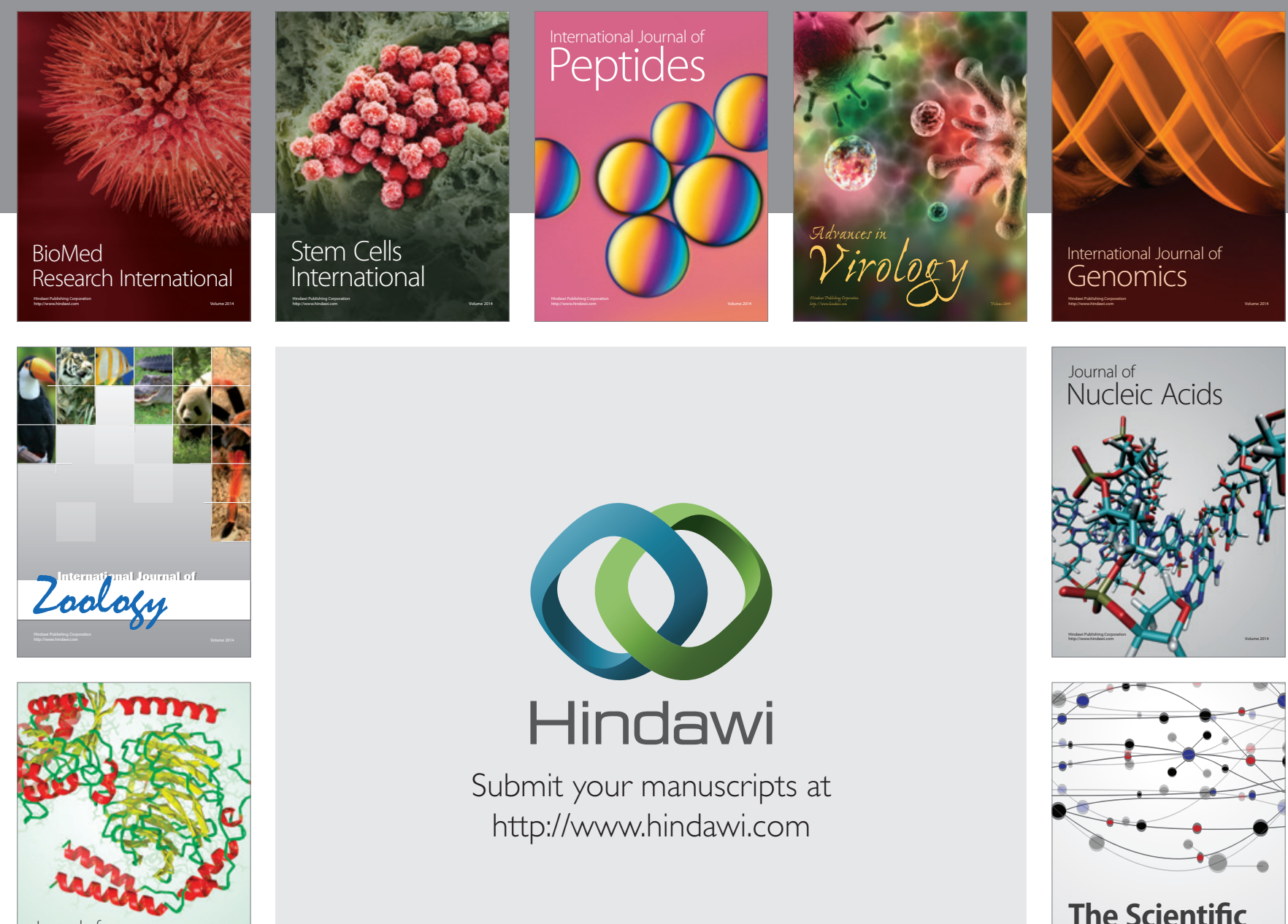

Submit your manuscripts at

http://www.hindawi.com

Journal of
Signal Transduction
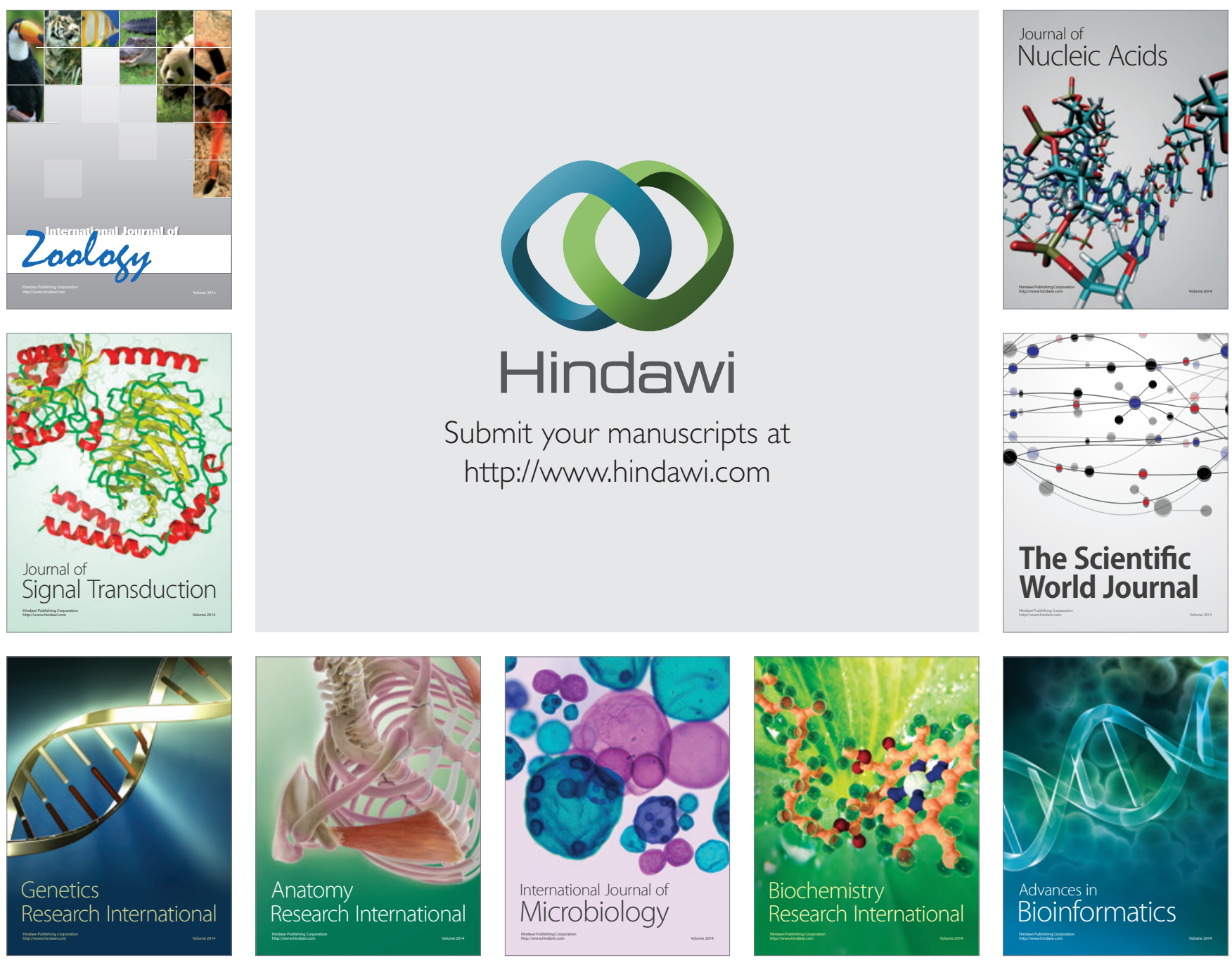

The Scientific World Journal
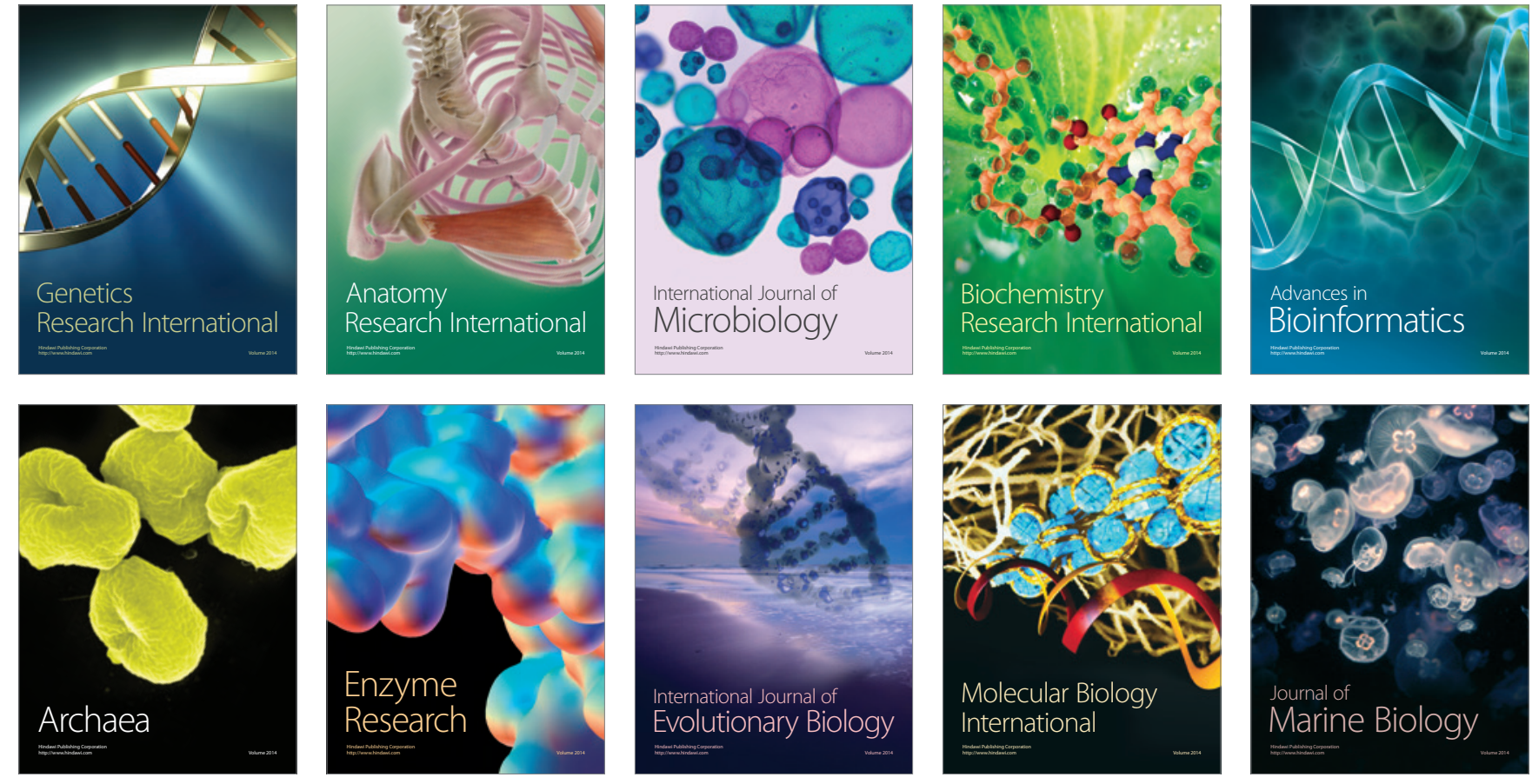